\title{
Induction of Indirect Somatic Embryogenesis on Embryonic Axis of TRI2025 Tea Clone
}

\author{
Ratna D. Eskundari ${ }^{1}$, Taryono Taryono ${ }^{2,4}$, Didik Indradewa ${ }^{2} \&$ Yekti A. Purwestri ${ }^{1,3}$ \\ ${ }^{1}$ Department of Biotechnology, Graduate School of Gadjah Mada University, Yogyakarta, Indonesia \\ ${ }^{2}$ Faculty of Agriculture, Gadjah Mada University, Yogyakarta, Indonesia \\ ${ }^{3}$ Faculty of Biology, Graduate School of Gadjah Mada University, Yogyakarta, Indonesia \\ ${ }^{4}$ Agrotechnology Innovation Centre, Gadjah Mada University, Yogyakarta, Indonesia \\ Correspondence: Taryono Taryono, Agrotechnology Innovation Centre, Gadjah Mada University, Yogyakarta, \\ Indonesia. Tel: 62-274-497-717. E-mail: tariono60@ugm.ac.id; tariono60@gmail.com
}

\author{
Received: May 31, $2018 \quad$ Accepted: August 3, $2018 \quad$ Online Published: September 15, 2018 \\ doi:10.5539/jas.v10n10p224 URL: https://doi.org/10.5539/jas.v10n10p224
}

The research is financed by the Ministry of Research, Technology and Higher Education of the Republic of Indonesia.

\begin{abstract}
Tea (Camellia sinensis L.) is classified as cross-pollinated crop and vegetative multiplication becomes commercially the main method of propagation with some limitations such as high heterogeneity and poor in survival rate and also in rooting. A proven tissue culture method, somatic embryogenesis, is the only challenging way to meet the needs of tea seedlings in large quantities. The study was conducted with TRI2025 tea clone selected from Polyclonal garden of PT. Pagilaran (Batang, Central Java). The explants were cultured on MS media supplemented with four concentrations of 2,4-D $\left(0,1,2\right.$, and $\left.5 \mathrm{mg} \mathrm{L}^{-1}\right)$ in two incubation conditions; dark and light. The results showed the only concentration of 2,4-D that can induce somatic embryo was $2 \mathrm{mg} \mathrm{L}^{-1}$ 2,4-D in light condition and its percentage was about 5\%. Other concentrations of 2,4-D that given for treatments both in two conditions will not induce somatic embryo. This study needs more improvements for getting powerful and efficient of method to get somatic embryo-derived plant and also for futher successful genetic engineering of tea biotechnology.
\end{abstract}

Keywords: auxin, Camellia sinensis L., in vitro, tissue culture

\section{Introduction}

Tea (Camellia sinensis L.) is classified as self-incompatible characteristic of crops (Chen et al., 2012), therefore its propagation using seeds is not desirable because seed derived progenies showed heterogenity (Mondal, Bhattacharya, \& Ahuja, 2001). For commercial purposes, vegetative propagation through stem cutting became the main method, but the multiplication is very slow with low survival rate and season depending rooting (Boonerje, Hoque, \& Sarker, 2013). The propagation by in vitro culture method is one choice for multiplication from any plant part due totipotency (Thorpe, 2007).

In tea, there are many reports about somatic embryogenesis with various kinds of explants and also of PGRs used. A $100 \%$ successful of somatic embryogenesis on embryo axis of tea using MS media supplemented with 2,4-D was reported by Kaviani (2013) and its cotyledon region was successful induced directly of its capability of somatic embryogenesis using MS media supplemented with ABA and osmoticum agent (PEG) (Suganthi et al., (2012). Ghanati and Iskha (2009) also reported the successful of indirectly induction somatic embryogenesis from leaf tea using modified B5 media supplemented with ABA and BA but without shoot formation, while Seran et al., (2006) was successful indirectly induced somatic embryo of about $8.3 \%$ from the same explants using MS media supplemented with BAP and NAA. A half strength of MS media supplemented with BAP was used by Tahardi et al., (2000) using cotyledon explants of Yabukita tea clone to induce somatic embryo with embryogenic convertion of about 56.6\%. Previously, nodal segment of tea was also $60 \%$ successfully induced its capability of somatic embryogenesis when cultured on modified MS media free of PGRs (Akula \& Dodd, 1998). 
Betaine and ABA was also reported to be effective to induce $15-20 \%$ of somatic embryo from mature seed of tea cultured on MS media (Akula et al., 2000). The success through present investigation is expected to help in development of biotechnology tools to improve quality and quantity of tea production.

Aseptic techniques of culture media preparations, selection of explants, and proper use of plant growth regulators (PGRs) in standardization of tissue culture protocol are the key factors in achieving successful somatic embryogenesis. Previous literature reported that MS media (Murashige \& Skoog, 1962) was the most commonly used media for tissue culture by several researchers. Next, PGRs is also one key of tissue culture successful factors. There are many PGRs for plant tissue culture, one of them is auxin; the only one PGRs used in this study. Auxin(s) is known as one of plant growth regulators that has many roles related to every development stage in a plant. In early response of injured plant; callusing; auxin plays an important role there (Xu et al., 2018). Auxin is also reported to be connected to root development (Overvoode et al., 2010). In tea tissue culture, both ex-vitro or in-vitro rooting, auxin was used (Ranaweera et al., 2013; Gonbad et al., 2014). Although auxin's role for rooting, but its role for shooting was also reported (Sandal et al., 2005). Its role to plant development might be due to its capability to involve at cell division and patterning (Perrot-Rechenmann, 2010).

2,4-D (2,4-dichlorophenoxy acetic acid) is growth promoting hormones at various concentrations and often used for tissue culture, especially to induce somatic embryogenesis (Raghavan, 2004; de Alcantara, 2014). Kaviani (2013) reported that the successful somatic embryos derived from tea's embryo axis using MS media supplemented with 2,4-D, but explants source details of clone were not provided. Here, we also chose embryonic axis for explants source; in line also with Seran et al. (2006) that stated it derived from meristematic tissue so that the possibility of somatic embryo production will be high. The TRI2025 clone we used for this study, with consideration that TRI2025 tea clone is known for its high productivity in various elevation of planting area (Sriyadi et al., 2012). The present investigation is the first report of somatic embryo from TRI2025 using embryonic axis and with induction of 2,4-D.

\section{Materials and Methods}

\subsection{Plant Materials}

Young seeds ( 8 months after seed set forming) (Figures 1A-1E) of TRI2025 tea clone harvested in Polyclonal garden at PT.Pagilaran were used as explants. Sterilization was carried out by washing explants using anti-microbes (Agrept $20 \mathrm{WP}$; Streptomycin sulphate 20\%) and anti-fungal (Dithane M-45; Mankozeb 80\%) solution followed by soaking in $96 \%$ alcohol for 10 minutes. The seed then to be burned for a few seconds and then tea seed coat was split open upon burning and embryo axis was excised prior to cotyledonary stage and before the seed germination for tissue culture. Embryoic axis is cut at part of growing points at shoot apical meristem (SAM) and root apical meristem (RAM) carefully using scalp knife and cultured on media tested. Explants were cultured on MS media supplemented with $0,1,2$, and $5 \mathrm{mg} \mathrm{L}^{-1}$ of 2,4-D, with $3 \%(\mathrm{w} / \mathrm{v})$ sucrose and solidified using $0.8 \%(\mathrm{w} / \mathrm{v})$ agar. This media was adjusted to $5.6 \mathrm{of} \mathrm{pH}$ prior to autoclaving.

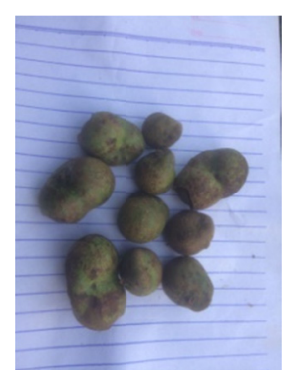

A

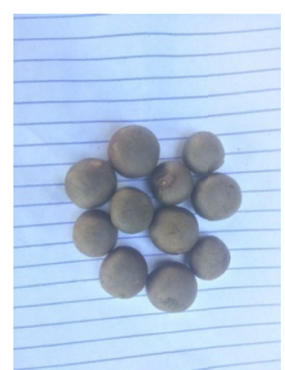

B

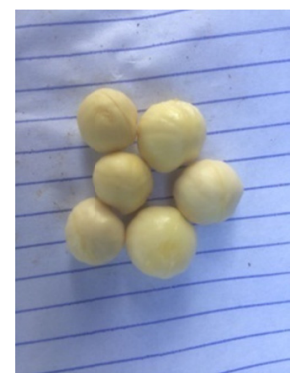

$\mathrm{C}$

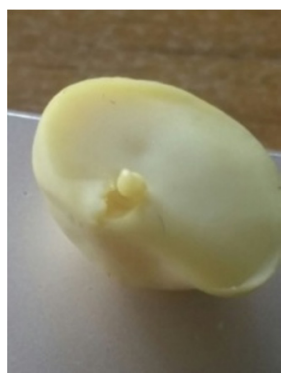

$\mathrm{D}$

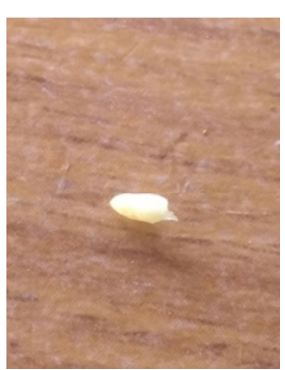

$\mathrm{E}$

Figure 1. TRI2025 seed. With its outer shell (A); with seed coat (B); seed coat removed (C); Cotyledon with embryonic axis (D); Excised embryonic axis before incision of growth points (E)

\subsection{Tissue Culture Condition}

Selected explants were removed their growth points and then cultured on MS media supplemented with various concentrations of 2,4-D $\left(0,1,2\right.$, and $\left.5 \mathrm{mg} \mathrm{L}^{-1}\right)$ and then incubated in dark and light conditions. All cultures wereincubated on $\pm 23{ }^{\circ} \mathrm{C}$. Especially for light condition was used daylight lamp of about $60 \mu \mathrm{mol} \mathrm{m} \mathrm{m}^{-2} \mathrm{~s}^{-1}$ 
intencity and for dark treatment, the explants were maintained on dark-box free of light. The time of morphological initiation response was recorded. After 4 weeks, the percentage of responsive explants as well as its color and shape were recorded.

\subsection{Statistical Analysis}

This research was conducted in a completely randomized design with 4 replicates of bottles and 5 explants in each bottle. The data were analyzed statistically using F-test and the means among each treatment were analyzed separately using Duncan's Multiple Range Test (DMRT). Software SAS 9.1 was used for all statistical analyzes and value of $\mathrm{p}<0.05$ was considered significant.

\section{Results and Discussion}

Explants cultured on MS media supplemented with 1, 2, and $5 \mathrm{mg} \mathrm{L}^{-1}$ 2,4-D gave callus response about 7 days after culture (DAC), while $0 \mathrm{mg} \mathrm{L}^{-1}$ 2,4-D did not give callus response. Callus was observed first developing in former incision region of all explants. After 1 month of culturing, these explants formed globular-like structure (GLS) in both light and dark condition (Figure 2,3).

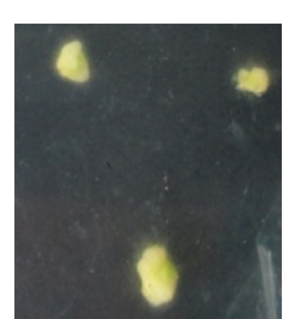

A: 0- DAC

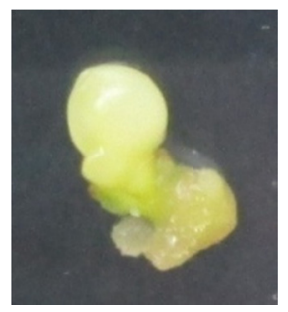

B: 30- DAC in dark

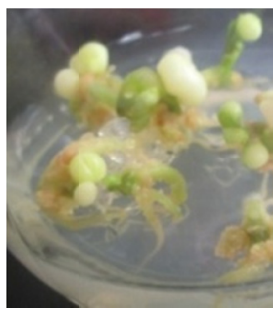

$\mathrm{C}: 120-\mathrm{DAC}$ in dark

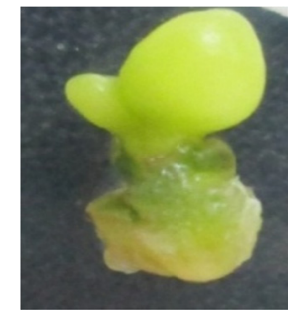

D: 30- DAC in light

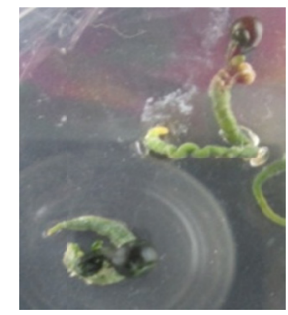

E: $120-$ DAC in light

Figure 2. Explants (A-E) cultured on MS media supplemented with $1 \mathrm{mg} \mathrm{L}^{-1}$ 2,4-D incubated in dark and light condition

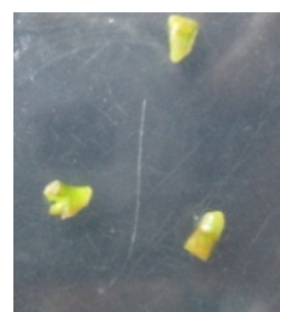

A

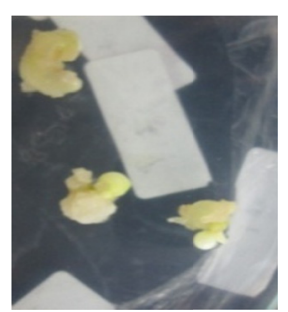

B

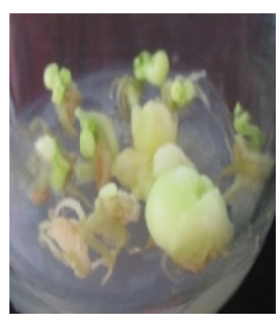

$\mathrm{C}$

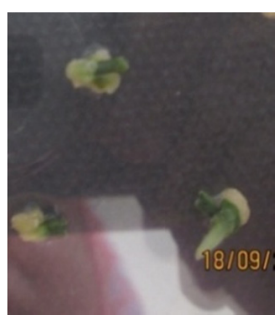

D

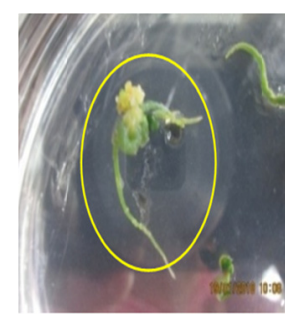

E

Figure 3. Explants cultured on MS media supplemented with $2 \mathrm{mg} \mathrm{L}^{-1}$ of 2,4-D incubated on dark and light condition. A: Explant 0-DAC; B: explant of 30 DAC in dark; C: explants of 120 DAC in dark; D: explant of 30

DAC in light; E: explants of 120 DAC in light. Yellow circle means explant produces embryo somatic(s)

Table 1. Effect the different concentration of 2,4-D in dark or light condition, on initiation of embryo somatic

\begin{tabular}{lll}
\hline Condition & {$[2,4-\mathrm{D}]$} & Mean of embryo somatic initiation \\
\hline Dark & 0 & $0^{\mathrm{b}}$ \\
& 1 & $0^{\mathrm{b}}$ \\
& 2 & $0^{\mathrm{b}}$ \\
Light & 5 & $0^{\mathrm{b}}$ \\
& 0 & $0^{\mathrm{b}}$ \\
& 1 & $0^{\mathrm{b}}$ \\
& 2 & $0.05^{\mathrm{a}}$ \\
\hline
\end{tabular}


Somatic embryogenesis of explant was observed on MS media supplemented with $2 \mathrm{mg} \mathrm{L}^{-1}$ 2,4-D incubated in light condition (Figure 3E; yellow circle). Somatic embryo structures emerged indirectly from embryo axis through callus formation. This callus was crumbs and yellowish-white in color. Afterward, explants were sub-cultured on MS free PGRs media that resulted in various later stages of developments in somatic embryo such as an elongated embryo and early-cotyledonary stage. Somatic embryogenesis was not observed on explants cultured on MS media supplemented with 0,1 , and $5 \mathrm{mg} \mathrm{L}^{-1}$ 2,4-D.

In light condition, explants receiving $2 \mathrm{mg} \mathrm{L}^{-1}$ 2,4-D treatment showed normal growth in 5 to 8 weeks after culture (Figures 4A-4B), and somatic embryo was emerged on surface of callus after 12 weeks (Figure 4C), exactly near the new taproot-developed. Then, explant's development (Figure 4D) was marked by development of somatic embryo growth elongation of its taproot.

The somatic embryo emerged indirectly, first preceded by callus production (Figure 4E) with a percentage of about 5\% (Table 1). This somatic embryogenesis was asynchrony in embryo stage development, some were on globular and others were on elongated embryo and early-cotyledonary stage.

The present results from successful indirect somatic embryo induction were observed similar to the findings of Kaviani (2013) indicating that 2,4-D with $1 \mu \mathrm{M}$ concentration successfully induced embryogenesis on embryo axis but directly. In contrast, this study contradicted with Vieitez and Barciela (1990) that 2,4-D can be used in inducing callus but inhibited the production of somatic embryo.

Globular stage was observed on surface of callus region in about 3 months after culturing. These globular embryos were transparent in color and clustered (Figure 4F). After globular stage, an elongated embryo was appeared, then changed to dark-green in color and later was observed like torpedo in structure (Figure 4G). Globular somatic embryo was also achieved by culturing nodal cutting of the same tea clone; TRI2025, on MS media with modification of media composition without any addition of PGRs (Akula \& Dodd, 1998). This means that TRI2025 tea clone can be induced its embryogenic capability through different explants.

Early-cotyledonary stage was also seen on this somatic embryo on about 5 months after culturing. Its color was light-green initially and then changed to dark-green. It showed a basin-like structure with concave shape on its surface (Figures 4H and 4I). These observed changes apperared after sub-culturing on MS free PGRs media, but were completely different from those reported by Suganthi et al. (2012) on successful of embryo somatic maturation sub-cultured onto MS media supplemented with osmotic agent (polyethylene glycol $=$ PEG) and absisic acids (ABA).

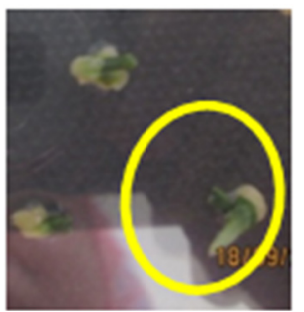

A

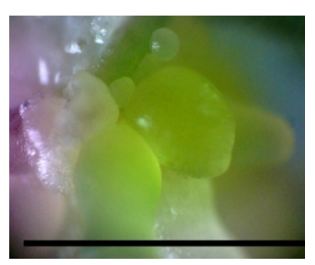

F

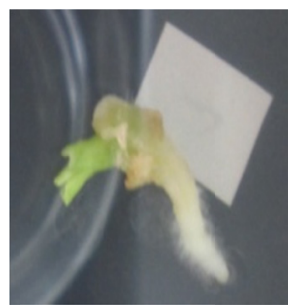

B

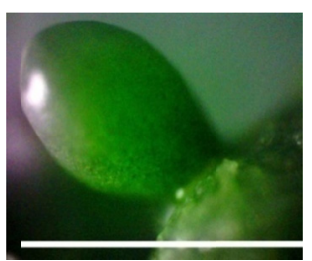

G

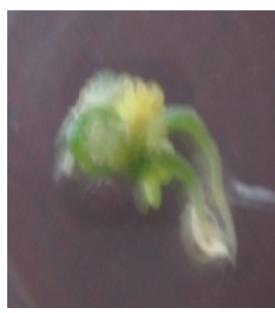

C

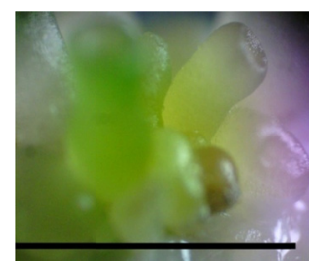

H

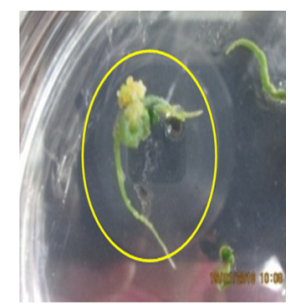

D

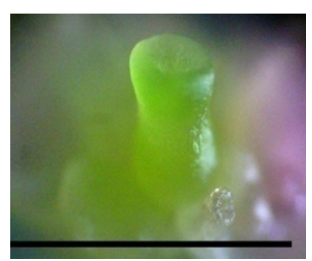

I

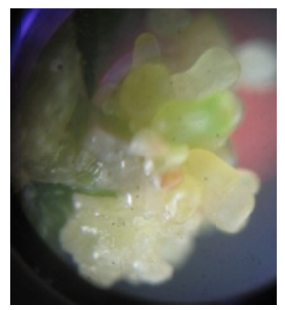

E

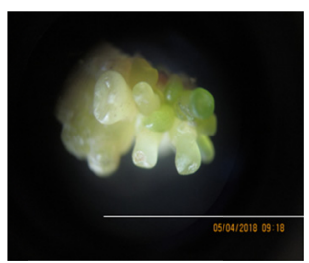

J

Figure 4. Stages of indirect somatic embryogenesis from embryo axis of TRI2025

A: 1 Month After Culture (MAC); B: 2 MAC; C: 3 MAC; D: 4 MAC; E: Callusing followed by embryo somatic; F: Globular stage; G: Elongated embryo: H: Yelllow early-cotyledonary stage; I: Green early-cotyledonary stage; J: Abnormal cotyledone. Bars: $10 \mathrm{~mm}$ 
In the present this study, cotyledonary stage was abnormal in structure (Figures $4 \mathrm{H}-4 \mathrm{~J}$ ) that was indicated with fused cotyledon forming. In tea, cotyledonary stage must has two cotyledon, so in this study, failure for gaining a normal cotyledonary stage might be due to stress condition. Another abnormal cotyledonary stage can be also caused by application of auxin transport inhibitor, such as N-1-naphthylphthalamic acid (NPA) (Hakman et al., 2009; Abrahamssons et al., 2012).

The somatic embryo was in early-cotyledonary stage and germination stage has not occurred yet. This was a challenge to choose best media for germination. Kaviani (2013) reported that tea somatic embryo from early to the end stage was only cultured on MS media supplemented with 2,4-D. This was different from previous reports of any tea clone or kind of tea explants (Akula \& Dodd, 1998; Akula, 2000; Tahardi et al., 2003).

Successful induction of somatic embryo in light or dark condition was different among plants. Somatic embryogenesis can be achieved in dark condition (Tahardi et al., 2000; Gomes et al., 2006), dark condition followed by light treatment (Sunandar et al., 2017), or fully in light condition (de-la-Pena et al., 2008; Bakhshaie et al., 2010; Lema-Ruminska \& Kulus, 2012). In tea micropropagation, light was also important to induce somatic embryogenesis (Akula et al., 2000, Akula \& Dodd, 1998) and were in confirmation of the present results of successful induction of somatic embryogenesis when explants were culture on light condition. The critical role of light capability to induce somatic embryogenesis was related proteins, such as a kind of arrestin-like protein, G-protein, and nucleoside diphosphate kinase (NDPK) (Nato et al., 2000).

Previously, Kaviani (2013) successfully induced somatic embryo on explants of embryonic axis of tea seed that are similar to the present study. Akula and Dodd (1998) also successfully induced somatic embryo of tea using different explants; nodal segment on modification of MS media. Therefore, present and previous findings are indicating that successful induction of embryogenesis requires several favorable factors and is highly specific specific to the type of tea clone, explants, culturing media, PGRs, incubation and suitable growing conditions.

General initial response for almost every explants cultured on all media tested was callus production. This phenomenon was observed due to former incision of root meristem to remove its growth point and was a common practice in plant tissue culture (Iwase et al., 2011). Callus was a crumb and yellowish-white in color that formed at about 7 DAC. In contrast, the apical meristem incision was not entered callogenesis stage, except in explants cultured on MS media supplemented with $5 \mathrm{mg} \mathrm{L}^{-1}$ 2,4-D.

\section{Conclusion}

This study successfully induced somatic embryo indirectly on embryonic axis of TRI2025 tea clone cultured on MS media supplemented with $2 \mathrm{mg} \mathrm{L}^{-1}$ of 2,4-D in light. Globular and elongated embryo was successful produced by culturing on MS media free PGRs, but subsequently abnormal early-cotyledonary was formed.

\section{Acknowledgements}

The writers would like to say thankful to PT. Pagilaran for supplying fruit of TRI2025 tea clone as explants and Ministry of Research, Technology and Higher Education for scholarship of BPPDN-DIKTI.

\section{References}

Abrahamsson, M., Valladares, S., Larsson, E., Clapham, D., \& von Arnold, S. (2012). Patterning during somatic embryogenesis in Scots pine in relation to polar auxin transport and programmed cell death. Plant Cell Tissue Organ Culture, 109, 391-400. https://doi.org/10.1007/s11240-011-0103-8

Akula, A., \& Dodd, W., A. (1998). Direct somatic embryogenesis in a selected tea clone, 'TRI-2025' (Camellia sinensis (L.) O. Kuntze) from nodal explants. Plant Cell Reports, 17, 804-809.

Akula, A., Akula, C., \& Bateson, M. (2000). Betaine a novel candidate for rapid induction of somatic embryogenesis in tea (Camellia sinensis (L.) O. Kuntze). Plant Growth Regulation, 30, 241-246. https://doi.org/10.1023/A:1006323213621

Bakhshaie, M., Babalar, M., Mirmasoumi, M., \& Khalighi, A. (2010). Effects of light, sucrose, and cytokinins on somaticembryogenesis in Lilium ledebourii (Baker) Bioss.via transverse thin cell-layer cultures of bulblet microscales. The Journal Horticultural Science and Biotechnology, 85, 491-496.

Boonerjee, S., Hoque, M., I., \& Sarker, R., H. (2013). Development of in vitro micro propagation system in tea plant (Camelia sinensis (L.) O. Kuntze) using shoot tip and nodal segment explants. Tea Journal of Bangladesh, 42, 21-30.

Chen, X., Hao, S., Wang, L., Fang, W., Wang, Y., \& Li, X. (2012). Late-acting self-incompatibility in tea plant (Camellia sinensis). Biologia, 67, 347-351. https://doi.org/10.2478/s11756-012-0018-9 
de Alcantara, G., B., Dibax, R., de Oliveira, R., A., Filho, J., C., B., \& Daros, E. (2014). Plant regeneration and histological study of the somatic embryogenesis of sugarcane (Saccharum spp.) cultivars RB855156 and RB72454. Acta Scientarum Agronomy, 36, 63-72. https://doi.org/10.4025/actasciagron.v36i1.16342

de-la- Pena, C., Galaz-Avalos, R., M., \& Layola-Vargas, V., M. (2008). Possible role of light and polyamines in the onset of somatic embryogenesis of Coffea canephora. Molecular Biotechnology, 39, 215-224. https://doi.org/10.1007/s12033-008-9037-8

Ghanati, F., \& Ishka, M., R. (2012). Investigation of the interaction between abscisic acid (ABA) andexcess benzyladenine (BA) on the formation of shoot in tissue culture of tea (Camellia sinensis L.). International Journal of Plant Production, 3, 7-14.

Gomes, F., L., A., F., Heredia, F., F., Silva, P., B., Faco, O., \& Campos, F. (2006). Somatic embryogenesis and plant regeneration in Opuntia ficus-indica (L.) Mill. (Cactaceae). Scientia Horticulturae, 108, 15-21. https://doi.org/10.1016/ j.scienta.2005.12.007

Gonbad, R., A., Sinniah, U., R., Aziz, M., A., \& Mohamad, R. (2014). Influence of Cytokinins in Combination with GA3 on Shoot Multiplication and Elongation of Tea Clone Iran 100 (Camellia sinensis (L.) O. Kuntze). The Scientific World Journal, 1-9. https://doi.org/10.1155/2014/943054

Hakman, I., Hallberg, H., \& Palovaara, J. (2009). The polar auxin transport inhibitor NPA impairs embryo morphology and increases the expression of an auxin efflux facilitator protein PIN during Picea abies somatic embryo development. Tree Physiology, 29, 483-496. https://doi.org/10.1093/treephys/tpn048

Iwase, A., Mitsuda, N., Koyama, T., Hiratsu, K., Kojima, M., Arai, T., ... Ohme-Takagi, M. (2011). The AP2/ERF transcription factor WIND1 controls cell dedifferentiation in Arabidopsis. Current Biology, 21, 508-514. https://doi.org/10.1016/j.cub.2011.02.020

Kaviani B. (2013). Somatic embryogenesis and plant regeneration from embryonic axes and cotyledons explants of tea (Camellia sinenis L.). Journal of Ornamental Plants, 3, 33-38.

Lema-Ruminska, J., \& Kulus, D. (2012). Induction of somatic embryogenesis in Astrophytum asterias (Zucc.) Lem. In the aspect of light conditions and auxin 2,4-D concentrations. Acta Scientiarum Polonorum. Hortorum Cultus, 11, 77-87.

Lu, J., Chen, R., Zhang, M., da Silva, J., A., T., \& Ma, G. (2013). Plant regeneration via somatic embryogenesis and shoot organogenesis from immature cotyledons of Camellia nitidissima Chi. Journal of Plant Physiology, 170, 1202-1211. https://doi.org/10.1016/j.jplph.2013.03.019

Mondal, T., Bhattacharya, A., \& Ahuja, P., S. (2001). Induction of synchronous secondary somatic embryogenesis in Camellia sinensis (L.) O. Kuntze. Journal of Plant Physiology, 158, 945-951. https://doi.org/10.1078/ 0176-1617-00179

Murashige, T., \& Skoog, F. (1962). A revised medium for rapid growth and bio assays with tobacco tissue cultures. Physioligia Plantarum, 15, 473-497. https://doi.org/10.1111/j.1399-3054.1962.tb08052.x

Nato, A., Fresneau, C., Moursalimova, N., Buyser, J., D., Lavergne, D., \& Henry, Y. (2000). Expression of auxin and light-regulated arrestin-like proteins, $\mathrm{G}$ proteins and nucleoside diphosphate kinase during induction and development of wheat somatic embryos. Plant Physiology Biochemistry, 38, 483-490. https://doi.org/ 10.1016/s0981-9428(00)00769-5

Overvoorde, P., Fukaki, H., \& Beeckman, T. (2010). Auxin Control of Root Development. Cold Spring Harb Perspectives in Biology, 2, a001537. https://doi.org/10.1101/cshperspect.a001537

Perrot-Rechenmann, C. (2010). Cellular Responses to Auxin: Division versus Expansion. Cold Spring Harb Perspectives in Biology, 2, a001446. https://doi.org/10.1101/cshperspect.a001446

Ranaweera, K., K., Gunasekare, M., T., K., \& Eeswara, J. (2013). Ex Vitro rooting: A low cost micrpropagation technique for Tea (Camellia sinensis (L.) O. Kuntz) hybrids. Scientia Horticulturae, 155, 8-14. https://doi.org/10.1016/j.scienta.2013.03.001

Raghavan V. (20004). Role of 2,4-dichlorophenoxyacetic acid (2,4-D) in somatic embryogenesis on cultured zygotic embryos of Arabidopsis: Cell expansion, cell cycling, and morphogenesis during continuous exposure of embryos to 2,4-D. American Journal of Botany, 91, 1743-1756.

Sandal, I., Kumar, A., Bhattacharya, A., Sharma, M., Shanker, A., \& Ahuja, P. S. (2005). Gradual depletion of 2,4-D in the culture medium for indirect shootregeneration from leaf explants of Camellia sinensis (L.) O. Kuntze. Plant Growth Regulation, 47, 21-127. https://doi.org/10.1007/s10725-005-3254-y 
Seran, T., H., Hirimburegam, K., Gunasekare, M. T. K. (2006). Somatic embryogenesis from embryogenic leaf callus of tea (Camellia sinensis L. O Kuntze.). Tropical Agricultural Research, 18, 367-375.

Sriyadi B., Suprihatini R., \& Khomaeni, H. S. (2012). The Development of High Yielding Tea Clones to Increase Indonesian Tea Production. Global Tea Breeding. Advanced Topics in Science and Technology in China. Springer, Berlin, Heidelberg. https://doi.org/10.1007/978-3-642-31878-8_10

Suganthi, M., Arvinth, S., \& Raj Kumar, R. (2012). Impact of osmotica and abscisic acid on direct somatic embryogenesis in tea. International Journal of Plant Research, 2, 22-27. https://doi.org/10.5923/ j.plant.20120202.04

Sunandar, A., Dorly, \& Supena, E., D., S. (2017). Induction of somatic embryogenesis in Sengon (Falcataria moluccana) with thidiazuron and light treatments. HAYATI Journal of Biosciences, 24, 105-108. https://doi.org/10.1016/j.hjb.2017.08.002

Tahardi, J., S., Raisawati, T., Riyadi, I., \& Dodd, W., A. (2000). Direct somatic embryogenesis and plant regenerationin tea by temporary liquid immersion. Menara Perkebunan, 68, 1-9. https://doi.org/10.22302/ ppbbi.jur.mp.v68i1.133

Tahardi, J., S., Riyadi, I., \& Dodd, W., A. (2003). Enhancement of somatic embryo development and planlet recovery in Camelia sinensis by temporary liquid immersion. Jurnal Bioteknologi Pertanian, 8, 1-7.

Thorpe, T., A. (2007). History of plant tissue culture. Molecular Biotechnology. Molecular Biotechnology, 37, 169-180. https://doi.org/10.1007/s12033-007-0031-3

Vieitez, A., M., \& Barciela, J. (1990). Somatic embryogenesis and plant regeneration from embryonic tissues of Camellia japonica L. Plant Cell. Tissue Organ Culture, 21, 267-274. https://doi.org/10.1007/bf00047620

Xu, C., Cao, H., Zhang, Q., Wang, H., Xin, W., Xu, E., ... Hu, Y. (2018). Control of auxin-induced callus formation by bZIP59-LBD complex in Arabidopsis regeneration. Nature Plants, 4, 108-115. https://doi.org/ 10.1038/s41477-017-0095-4

\section{Copyrights}

Copyright for this article is retained by the author (s), with first publication rights granted to the journal.

This is an open-access article distributed under the terms and conditions of the Creative Commons Attribution license (http://creativecommons.org/licenses/by/4.0/). 